\title{
Introduction: New World Encounters
}

A $\mathrm{T}$ The chose of Samuel Eliot Morison's monumental study, The European Discovery of America: The Southern Voyages, 1492-1616, the great historian salutes the ships-Santa Maria, Niña, Golden Hind, and so forth-that carried Europeans across the face of the earth in what he views as a secular epiphany. This century of voyages was also, Morison observes, an epiphany in the religious sense:

The main conception and aim of Columbus, to carry the Word of God and knowledge of His Son to the far corners of the globe, became a fact: Christ had been made manifest to a new race of Gentiles. By 1615 the Christian Mass was being celebrated in hundreds of churches from the St. Lawrence through the Antilles to the River Plate, and along the west coast from Valdivia to Lower California. To the people of this New World, pagans expecting short and brutish lives, void of hope for any future, had come the Christian vision of a merciful God and a glorious Heaven. And from the decks of ships traversing the two great oceans and exploring the distant verges of the earth, prayers arose like clouds of incense to the Holy Trinity and to Mary, Queen of the Sea. ${ }^{1}$

Morison's words, published in 1974 near the end of his long and distinguished career, can conveniently stand as the articulation of a traditional position-let us call it "the vision of the victors"-against which all of the essays in this volume, however diverse their interests and conclusions, are written. ${ }^{2}$ It is not that these essays are explicitly concerned to refute this position; rather, they seem to inhabit a different century, one that has seen all of the assumptions behind Morison's eloquent sentences decisively challenged.

For the contributors to this volume, the European voyages of the sixteenth century did not constitute an epiphany-though not because these essays simply dismiss the Europeans' religious motives. Such a dismissal was characteristic of an earlier critique of colonialist apologetics, a critique exemplified by a famous passage in Gulliver's Travels:

A Crew of Pyrates are driven by a Storm they know not whither; at length a Boy discovers Land from the Top-mast; they go on Shore to Rob and Plunder; they see an harmless People, are entertained with Kindness, they give the country a new Name, they take formal Possession of it for their King, they set up a rotten Plank or a Stone for a Memorial, they murder two or three Dozen of the Natives, bringing away a Couple more by Force for a Sample, return home, and get their Pardon. Here commences a new Dominion acquired with a Title by Divine Right. Ships are sent with the first Opportunity; the Natives driven 
out or destroyed, their Princes tortured to discover their Gold; a free Licence given to all Acts of Inhumanity and Lust; the Earth reeking with the Blood of its Inhabitants: and this execrable Crew of Butchers employed in so pious an Expedition, is a modern Colony sent to convert and civilize an idolatrous and barbarous People. ${ }^{3}$

There is, in my view, much to be said for Swift's vision, but it is no more that of the contributors to this volume than is Morison's. If there are in these essays few pious sailors hymning the Virgin from the decks of their stout ships, there are equally few cheerily cynical pirates. Even Sir Walter Ralegh, who was rumored in his own time to be an atheist, figures in these pages not as a man who stands coolly outside the ideological codes of his time but as someone who was engaged in a complex and often desperate negotiation with values he could neither securely manipulate nor comfortably embrace. Other Europeans whose texts are analyzed here-Pedro de Cieza de León, Bartolomé de Las Casas, Jean de Léry-are deeply engaged with the fate of Christianity in the New World, but their religious vision and its practical consequences bear little resemblance to that celebrated by Morison.

One way in which these essays differ sharply from the positions exemplified by Morison and Swift is that they are centrally concerned with what Nathan Wachtel called "the vision of the vanquished." 4 They share with other recent scholarship in Europe and the Americas a sense of alternative histories, competing accounts, and muffled voices. They attempt in a variety of ways to register the powerful presence of otherness-not an abstract, quasi-allegorical figure of the Other, whether brute or victim, but a diverse range of cultures and representations and individuals with whom the Europeans were forced to interact. Reading these essays, we come to realize that between Morison's celebrants and Swift's predators the very possibility, let alone the necessity, of such interaction had been lost. The American natives had in either case been rendered virtually transparent-either as Hobbesian pagans in a state of nature, condemned to lives that are solitary, nasty, brutish, and short, or as mute, naive, miserable victims, condemned only to deception and enslavement. The essays in this volume, by contrast, give to the encounter between Europeans and American peoples a remarkable specificity and historical contingency. The Indians have lost the transparency of allegory, gaining instead the density of historical subjects struggling to come to terms with figures from a perplexingly different culture. For their part, the Europeans are also not to be understood as allegorical representatives of monolithic traditions, but as figures who are improvising sinuous paths through fiercely competing claims.

This mutual density does not necessarily signal successful communication between the historical subjects. On the contrary, as Inga Clendinnen shows in her brooding and powerful essay, the cultural understandings specific to Indian as well as Spanish warfare make communication virtually impossible. But the point is that even failed communication is two-way. The Spanish and the Mexicans had 
a common desire, the desire to make a meaningful story out of the disorienting, almost incomprehensibly violent events in which they were plunged.

The radical incompatibility of these compelling stories plays a crucial role, Clendinnen argues, in the outcome of their struggle-and it plays a crucial role as well in the story that she has to tell. For, as she acknowledges, the historian is by no means exempt from the compulsion to fashion a coherent and satisfying narrative out of the tangled traces of the past. This acknowledgment leads her to skepticism about her own sources, particularly the fragmentary early accounts of the initial clash between the small band of conquistadors and the Aztec empire. She proposes that we resist the Spanish presumption that their civilization gave them greater access to the mind of the other, and hence a strategically crucial advantage, a claim that has dominated accounts from those of Hernan Cortés to W. H. Prescott in the nineteenth century and to Tzvetan Todorov in our own. For Clendinnen, Cortés is not a model of intercultural understanding, strategic or otherwise, nor is he the embodiment of rational calculation. His gift, in her view, lay in his ability "to coax, bully, and bribe his men, dream-led, dream-fed, into making his own gambler's throw; to participate in his own desperate personal destiny." Her essay is a somber warning against confusing this fantastic exercise of the will-a violent imposition, in effect, of narrative on reality-with actual knowledge of another culture.

But if the historian herself is committed to imposing narrative on reality, how can she avoid replicating the very process she is attempting to analyze? There is no simple solution to this problem, I think, but one can glimpse in Clendinnen's essay repeated attempts to unsettle the very condition of a coherent and satisfying narrative of these events. Hence her account turns upon a central, structural incoherence, an untranslatability (as much for the Spaniards as for the Mexicans) that had and, she suggests, continues to have terrible consequences. What looks like communication is noncommunication; what looks like relationship is the absence of relationship; what looks like strategic understanding and cultural manipulation is the bloody clash of incompatible and mutually uncomprehending worlds. And the deepest incompatibility is the incompatibility of story making: Spanish stories trace "an intricate sequence of action" in order to produce "the familiar, powerful cumulative explanation through the narrative form"; Indian stories are founded on a different principle, one based on a conception of time "as multidimensional and eternally recurrent." The absolute noncoincidence of these modes did not cause the violent encounter of the Spanish invaders-“men without a city," as Clendinnen characterizes them-and the inhabitants of Mexico: blood would have been shed had both peoples understood each other perfectly. But the noncoincidence made it impossible to contain the killing within either culture's established ways of managing violence, impossible to bring the war to a close until the men without a city had utterly destroyed the city they had meant to conquer. 
We can perhaps usefully apply to the situation Clendinnen analyzes a concept that Fernand Braudel terms "the structure of the conjuncture." As adapted by Marshall Sahlins, the concept refers to the historical intersection of radically divergent cultural categories. ${ }^{5}$ Each side in an encounter between peoples who do not understand each other tries to make sense of the other's actions, and the particular meeting of these interpretations - the way they happen to fit together or to clash in a given historical situation-has profound consequences. In the conjuncture of Europeans and New World peoples not only were the respective cultural understandings vastly different, but the historical situations on each side, though superficially identical (ships arrive, objects are traded, blows are struck), were in fact equally far apart. For a historical situation is never simply that of the moment: it is the expression of long-term trajectories, material necessities, social structures, enduring, largely unconscious patterns of will and constraint, not necessarily identical with the culture's own understanding of itself or others.

Thus in the momentous encounters after 1492 four distinct elements repeatedly converge: the operative cultural understanding of the Europeans, the historical situation in which this understanding is deployed, the operative cultural understanding of the natives, and the historical situation in which this understanding is deployed. The convergence has its own structuring force, quite apart from what any of the participants may be thinking. The crucial point, for our purposes, is that the asymmetries, the virtually inevitable misunderstandings and confusions, were as consequential as any carefully crafted strategy-and not only in the production of violence. Hence, as Rolena Adorno's essay shows, Cabeza de Vaca stumbled into a situation where his actions, which initially threatened the security of the Indians among whom he found himself, subsequently became an essential instrument for their spiritual coherence. It is not clear how much Cabeza de Vaca himself understood his role in the strange and complex ritualized pillages he had triggered. He is a figure, in Adorno's account, at the center of a structural conjuncture that manipulates him at least as much as he manipulates it.

Does this mean that Cabeza de Vaca's understanding of his situation is irrelevant to his fate? Not at all. To survive and to make his way back to his countrymen, he had somehow to "negotiate away" the terrible fear with which he and his companions were understandably afflicted, and he had at the same time to negotiate away the fear that his presence aroused in the various groups of Indians he encountered. But, in the event, this negotiation of fear required the fortuitous conjunction of fundamentally divergent expectations, understandings, and practices. The acts of healing by which the Spanish ingratiated themselves to the Indians came to be strangely bound up with "ritual patterns of intertribal exchange and/or warfare." The two cultures produced, in effect, a discourse that neither could have fully understood-and it is as a result of this fusion, Adorno shows, that Cabeza de Vaca's extraordinary expedition narrated in the text known 
as the Naufragios came to "symbolize the benevolent and paradigmatic encounter of two worlds."

Faced with the challenge of radical difference, both Europeans and natives often behaved as if groping their way blindly through dense fog. The problem posed for action and understanding alike, in the wake of the European landfall in the Americas, is the need, as Anthony Pagden puts it, "to create a text where none had existed before" and "to make the text, once created, authoritative." Hence from the moment of landfall Columbus attempts to translate the practices of the alien world he observes into the practices of his own. This attempt to reduce the distance between the self and the other by "direct substitution" is one of the enduring principles of the early European response to unfamiliar lands and peoples, but it is set against the opposite response, the recognition of baffling and confounding otherness in the newly discovered lands and peoples. As Pagden demonstrates in a subtle analysis, the pivotal figure of Bartolomé de Las Casas conjoined the two responses, for Las Casas appeals both to a principle of identity (the Indians are "men like us") and a principle of eyewitness (only those who have seen for themselves can speak with authority). Pagden lines up these two principles with a tension in Las Casas between ius and factum, law and fact, canonical text and direct experience of the external world. Why should Las Casas's long personal experience of the New World not serve as a reliable basis for an authoritative text, a sure guide to the interpretation of the law as it applies to the peoples of America? The problem is that to European readers the experiences of the New World sounded like "the fables and lying tales of Amadis of Gaul"; the only way to confer a convincing reality upon them, Pagden suggests, would have been through a convincing "I"-an "I" that Las Casas the writer, whose passionate intelligence was not matched by his rhetorical skills, could never become.

Las Casas also has a critical role in Sabine MacCormack's essay, "Demons, Imagination, and the Incas." Starting with the Aristotelian conception, followed by Aquinas, that "the soul never thinks without a phantasm," MacCormack explores the ways in which Europeans tried to understand Inca religion. In classifying and categorizing what they were attempting to destroy, the Spanish tended, MacCormack notes, to detach Andean religious beliefs and ritual practices from the mythic and historical narratives that gave them meaning. The consequence was that the Spanish could not hope to comprehend Andean religion. Yet they feared its obvious power in the daily lives of the people, and they took seriously the many visionary manifestations of the Inca gods. Since the Aristotelian tradition held that sense perceptions, in themselves, could not be in error, European observers concluded that the Incas' beliefs in false gods must originate in an imagination that was led astray by demons. Hence, insofar as they recognized the cultural power of Andean religion, the Spanish could only attribute that power to the founding intervention of the devil. 
MacCormack argues that Las Casas made an important conceptual break with this explanatory tradition by demoting direct demonic intervention from primary cause to merely one of several causes of religious difference. But only when the indigenous culture no longer represented a significant threat, only when Andean religion no longer had teeth-and hence, to recall Durkheim's view, was scarcely a religion-could it be freed from the theory that its origin lay in satanic intervention in the imagination. For the Spanish observers in the first generations after the conquest, the power of Indian culture was inextricably intertwined with the agency of Satan. The Andean imagination was freed from the imputation of the demonic only by stripping it of its power-the power, for example, to induce widows to immure themselves in the graves of their dead husbands. At the far end of the intellectual development initiated by Las Casas is Spinoza, for whom the imagination is not the unreliable faculty that mediates between infallible sense perception and right reason, but rather the faculty that in itself lies outside the possibility of error. "For," Spinoza writes, "if the mind while it imagines nonexistent things as present to it at the same time knows that those things do not exist, it attributes this power of imagining to a virtue of its nature, not to a vice." But, of course, this view, if applied to Andean (or any other) religious imagination, would imply that its visions are empty, mere spectacles of "nonexistent things."

In "The Philosopher's Breviary," Frank Lestringant makes a somewhat comparable point about the French Enlightenment. The account of the Tupi Indians in Jean de Léry's extraordinary Histoire du Brésil-the text Lévi-Strauss has called "the breviary of the ethnologist"-is bound up with the Huguenot Léry's conviction that the "savages" among whom he lived for several months were under a divine curse and were predestined to eternal damnation. The philosophy of the Enlightenment, full of confidence in the triumph of Reason over gloomy superstition, took up the wonderfully evocative Huguenot discourse of the New World in order to produce the idealized figure of the Noble Savage. But in doing so the Enlightenment philosophers drastically reduced Léry's vision, for in stripping it of its "fanaticism"-its conviction that the natives were devil-worshipers doomed to the fires of hell-they also stripped it of its ethnographic intelligence and its emotional force. "Once the omnipresent curse springing from original sin is left out of Léry," Lestringant asks, "what remains of the poignancy of condemned children? His remarks become insipid when deprived of their theological dimension." The Enlightenment rationalized the uncanniness of Léry's cannibals, so profoundly appealing and so morally disturbing, and transformed them into nature's noblemen. In place of Léry's stunned vision of what Michel de Certeau calls "insurmountable alterity," the philosophers projected onto the Brazilian natives the phantasms and desires of the European imagination, in the process reducing their religion to mere trickery and imposture.

What would it mean neither to demonize an American culture nor to trans- 
form it into an idealized exotic reverie? Several answers are at least implied in these essays, particularly David Damrosch's "The Aesthetics of Conquest" and Sara Castro-Klarén's "Dancing and the Sacred in the Andes." As Damrosch notes, many contemporary Mesoamericanists see Aztec culture as sharply split between the terrifying violence of its military and religious practices and the haunting delicacy of its melancholy poetry. He proposes not that we abandon both viewsthey are too bound up in our sense of the world simply to discard-but rather that we place them in relation to each other in an act of cultural interpretation. Damrosch thus suggests that we view Aztec aestheticism not as a redemptive alternative to Aztec imperial policy but as "deeply implicated" in it. The poems are in this sense "impure": for all of their exquisite otherworldliness, they are actions in the world. They are impure in another sense as well: their blend of Christian and Aztec references cannot be neatly rearranged to reveal a pre- and post-Conquest religion and aesthetic. For Damrosch, this impurity-which renders us unable to know whether a given poem is responding to events of 1460 or 1560 , or perhaps to both-is not so much a liability of these texts as a source of their compelling power.

Damrosch posits a pre-imperial mode of poetry that was changed by the Aztec militarization of culture into a celebration of the beauty and terror of warfare: "Warfare is seen as an artistic act, and the warrior becomes a poet." The old images that evoked the fragility of life and the moral urgency of friendship are repeated, but now to cast an aura of beauty around imperial expansion and the suppression of revolts. After the Spanish conquest, this cycle of repetition and difference continues: "Within their own lifetimes, the Aztec poets were compelled to sing their poems in the light of the overturning of the world in which they were first composed." Their poems paradoxically insist on the continuity of their culture even in registering its destruction, and we are in consequence compelled to read many of them in a kind of double or triple sense. "The same images and verses that aided and even heightened the brutality of the imperial regime were turned to new purposes some years later: to strengthen the resolve of a conquered people to resist their total destruction."

The ruses and transcodings that enable continuity in the midst of disaster and oblivion are the subject of Sara Castro-Klarén's essay, "Dancing and the Sacred in the Andes." But the survival that principally interests her is located not in the sixteenth century, at the time that the "extirpators of idolatries" were doing their relentless work, but in the twentieth. In the cult and ritual dance known as the "Taqui-Oncoy"- a millenarian vision of the end of Spanish domination and the return of the Andean gods-Castro-Klarén finds the hermeneutic key to a resonant short story by a contemporary Peruvian writer, José María Arguedas. Her essay serves as an important reminder that this volume is not about peoples and cultures that "have vanished without a trace," but about encounters, strategies, contradictions, and struggles that continue into the present. 
If one of the key principles of this collection is that the native cultures were, in Damrosch's phrase, "impure"-that is, neither transparent nor timeless, but opaque, complex, and constantly changing - an equally important corollary is that the discourse of the colonizers was similarly impure. Their texts are overdetermined, crisscrossed by tiny fracture lines, characterized by unresolvable contradictions. These contradictions have famously plagued interpretation of Columbus's first letter, for which we now have an alternate version, translated into English for the first time by Margarita Zamora. This version, as Zamora observes, differs significantly from the celebrated letter that circulated in Europe in the wake of Columbus's first voyage, and its startling resurfacing after so many centuries subjects that letter to what Louis Montrose, in his illuminating analysis of Sir Walter Ralegh's Discoverie of Guiana, calls "epistemological and ideological destabilization."

The newly discovered version makes far more visible the peculiar yoking in Columbus's rhetoric, and perhaps in his consciousness, of piety and greed-the longing to recover for Christianity the holy places of Jerusalem and the equally intense longing to get the natives' gold in exchange for trash. This conjunction of apparently contradictory impulses is no accident; it is built into the structure of much of the period's colonialist discourse. Hence Ralegh's text, Montrose shows, attempts to mount a moral argument based on a cynical design, indeed boasts of a cynical use of moral pretense even as it insists on its ethical uprightness. In consequence, the Discoverie constructs for its author and reader alike a set of mutually contradictory positions-roughly akin to the pious evangelists and the ruthless pirates with which we began this introduction-whose incompatibility threatens fatally to undermine the manifest rhetorical intention of the work.

In "Ralegh's Fugitive Gold," Mary Fuller points out a comparable contradiction between the triumphalism of Ralegh's account of his expedition and the expedition's failure to bring back any substantial material proof of Ralegh's claims. Therefore, Fuller observes, Ralegh's Discoverie is forced perpetually to defer the completion of the quest, to point just beyond the horizon to the place where the gold of El Dorado forever awaits and eludes the seeker.

Ralegh's discourse, as Fuller and Montrose both observe, was not meant-any more than was Columbus's letter-to be an intriguing puzzle, a delicious game of vanishing points, dissolving promises, and ethical contradictions. It was meant to testify, to persuade, to provoke action. But how, given its internal rifts, could the Discoverie successfully intervene in the world? How could it persuade its readersand, above all, its royal reader-of anything? Faced with this dilemma, Montrose argues, Ralegh employs gendered language. In an attempt to stabilize the categories and shore up the distinctions on which he wishes to base his claim for the moral superiority of English imperialism, Ralegh writes of Guiana as a woman. This use of the figure of the woman is a time-honored expedient in such shaky rhetorical structures, but the problem for Ralegh is that he is in the service of a 
powerful female monarch toward whose authority he feels a deep and unresolvable conflict. Therefore, Montrose argues, while the "gendering" of Guiana ostensibly serves the imperial designs of Elizabeth I, it actually "stages a covert resistance to the queen's power." This resistance serves in turn further to destabilize Ralegh's errant text: a rhetorical strategy aimed at composing the conflicting elements of a troubled discourse into harmonious accord only intensifies the dissonance. For Ralegh there is no safe haven, no home port.

Textual dissonance is the subject as well of David Quint's "Voices of Resistance." Quint shows that the curses of the vanquished, so powerfully represented in Gaspar Perez de Villagrá's Historia de la Nueva Mexico and in Alonso de Ercilla's Araucana, are an epic topos that can be traced back to the Odyssey and the Aeneid. But what function does this topos, that seems to pull sharply against the triumphalism of epic, serve? In Quint's analysis, it appears to serve a double or split function: on the one hand, "it makes a good story"; on the other hand, it "calls the idea of ending"-and hence, perhaps, of making a good story- "into question." The epic curse raises the specter of people who will never be assimilated to the imperialists' new world order, never reconciled to their own subjugation. Like most curses, it is uttered from a position of powerlessness, but also in the expectation that powerlessness will not endure forever. It registers a tenacious refusal to submit to the narrative of the victors.

And yet, Quint points out, the epic curse is precisely one of the hallmarks of this narrative. As such, its presence can be viewed as a kind of sublime trophy of conquest, a sign of the containment of the rebellious spirit of the savage, the point at which barbarous speech submits to civilized writing. It may signal not a crack in the imperial ideology but the need for unceasing vigilance and the endless renewing of disciplinary will. In a subtle analysis of the Adamastor episode in Camões's Lusíadas, Quint shows that the half-stifled voices of resistance can be made to serve the celebration of the victors, and at the same time he argues that the unsettling power of the topos asserts itself even when it appears to be most repressed.

In an "Afterword," Quint associates the epic curse with a still more virulent curse that at least some Europeans felt had originated in America: syphilis. To this we may add another American specter that came to haunt Europe: tobacco. Jeffrey Knapp's "Elizabethan Tobacco" points out, however, that for many Englishmen tobacco was one of the highest blessings of the New World. Compared with the gold bullion that the Spanish treasure fleet regularly carried home from the Caribbean, tobacco seems, of course, like the most negligible trifle, but the apologists for the English colony in Virginia-a territory notably deficient in gold mines-persuaded themselves or tried to persuade others that tobacco was an even greater treasure. Tobacco's proponents praised the weed not only for its fabled medicinal powers-its ability to open the pores, clear the lungs, and warm the brain-but also for its exemplary spiritual qualities: its link to the imagination, 
its superiority to filthy lucre, its emblematic transformation of matter into spirit. Let the Spanish have the gold their slaves claw from the bowels of the earth, let the papists have the wafer-god they profess to swallow in the Mass; the stout Protestant Englishmen, happier by far, have "divine tobacco."

Were such arguments ever made seriously? Not quite. Yet, as Knapp shows, they were the hyperbolic articulation of a set of assumptions, ambitions, and compensatory dreams that characterize much of the discourse of colonialism, the religious ideology, and the poetry of early modern England. Even James I's angry denunciation of tobacco was not enough to turn his nation away from its obsession with turning smoke into profit and profit into smoke.

As this brief review should make apparent, the essays collected here represent a wide range of interests and approaches. But, with the exception of Margarita Zamora's translation of Columbus's letter and Sara Castro-Klarén's "Dancing and the Sacred," all have appeared in the journal Representations, most of them in a single issue dedicated to the memory of Michel de Certeau, and this common ground is not a neutral fact. Context does not constitute a unified or prescriptive program, but it does, as I have already hinted, imply certain shared critical principles that bring together the very different enterprises of history, ethnography, and literary criticism.

What are these principles? First, an assumption of textual opacity. All the essays start from the conviction that discourse neither can nor should be rendered transparent. We are allowed access to the European encounter with the New World chiefly through what de Certeau calls the colonists' "scriptural economy." Writing is itself freighted with meaning, particularly in texts about peoples whose identity the texts repeatedly characterized as bound up with their supposed lack of even the most rudimentary writing. The scholar's goal must not be to strip away or look behind European texts in order to discover the naked truth. The problem is not that there is no truth or that we are forever doomed to ignorance-though considerable ignorance is certainly inescapable in these mattersbut that the discourses of colonialism actually do much of the crucially important work of colonialism. Consequently, if we treat the texts as clear or even as distorting windows, we inevitably miss much of what we most need to understand:

Second, a recognition of textual complexity. The early European accounts of the encounter are not monolithic or single-minded. The essays in this volume are concerned with the half-hidden stress points in the official structures, the tensions, ideological negotiations, and rifts that are often plastered over in later accounts, all but disappearing from view. Many of the texts discussed here create complex intertwinings of potentially competing discourses, systems that are perilously close to explosion or collapse. It was, de Certeau argued, Montaigne's 
genius in "Of Cannibals" to bring matters to a crisis: the rival discourses "destroy one another as soon as they touch: a shattering of mirrors, the defection of images, one after the other."

Third, a search for textual otherness. The voices of the other do not reach us in pure or uncontaminated form-as if such a condition were ever possible! Indeed the whole European project of writing about the New World rests upon the absence of the object-landscape, people, voice, culture-that has fascinated, repelled, or ravished the writer. "The scriptural operation which produces, preserves, and cultivates imperishable 'truths," de Certeau writes, "is connected to a rumor of words that vanish no sooner than they are uttered, and which are therefore lost forever." Yet, despite this loss, the "rumor of words" must somehow be attended to. The difficulty of this task is the subject of many of these essays, as is the peril of a failure to attend.

Fourth and finally, a questioning of textual authority. Once they are written, texts do not simply appear in the world (or routinely survive in archives): they are marked, placed, licensed, authorized. "Writing," de Certeau observes, "designates an operation organized about a center." ${ }^{\prime 8}$ But in the case of the New World, the center very often does not hold. Textual authority is fraught with particular difficulties, not only because of perennial tensions in overburdened command structures, but because of the immense distance from Europe of the newly discovered lands and, consequently, the immense problem of verification, a problem exacerbated by the strangeness of the stories that had to be told. At the moment that Europeans embarked on one of the greatest enterprises of appetite, acquisition, and control in the history of the world, their own discourses became haunted by all that they could not control. They had embarked, without quite realizing it, on "a subtle, permanent, practice of distances."

\section{Notes}

1. Samuel Eliot Morison, The European Discovery of America: The Southern Voyages, 14921616 (New York, 1974), 737.

2. Among the many articulations of this traditional position, one might cite Leonardo Olschki's characterization of Spanish imperialism as "a human activity which transformed within a short lapse of time a rudimentary stone-age society into a lively colonial organization"; "What Columbus Saw on Landing in the West Indies," Proceedings of the American Philosophical Society 84 (1941): 635.

3. Jonathan Swift, Gulliver's Travels, ed. Ricardo Quintana (New York, 1958), 241.

4. Nathan Wachtel, The Vision of the Vanquished: the Spanish Conquest of Peru through Indian Eyes, 1530-1570, trans. Ben and Sian Reynolds (1971; New York, 1977).

5. See Marshall Sahlins, Islands of History (Chicago, 1985), esp. 125. 
6. Michel de Certeau, "Montaigne's 'Of Cannibals': The Savage 'I,'” in Heterologies: Discourse on the Other (Minneapolis, 1986), 71.

7. Michel de Certeau, The Writing of History, trans. Tom Conley (New York, 1988), 212.

8. Ibid., 217.

9. de Certeau, Heterologies, 68. 